\title{
ESSAY
}

\section{FORMALITIES AND FORMALISM IN THE UNIFORM PROBATE CODE}

\author{
BRUCE H. MANN†
}

"Down with formalism" has been the rallying cry of probate reform since 1975, when John H. Langbein published his landmark critique of formalism in wills adjudication. ${ }^{1}$ Thus, when Langbein himself announced that "curing intent-defeating formalism"2 was a driving force behind recent revisions of the Uniform Probate Code, commentators naturally hailed the "fall of formalism." Without question, portions of the new Code further the weakening of formalism that has characterized many areas of law in the second half of the twentieth century. A more accurate description of the new Code, however, would refer instead to the rather less stirring "fall of formalities," as it is the formal requirements for wills that have been most affected. Formalism itself still flourishes in the revised Code. Indeed, the new and, in many respects, improved Uniform Probate Code illustrates the enduring and perhaps inescapable tension over the role of formalism in private law adjudication-a subject that has occupied scholars as diverse as Roscoe Pound and Duncan Kennedy. ${ }^{4}$

† Professor of Law and History, University of Pennsylvania. I am grateful to John H. Langbein and Lawrence W. Waggoner for their generous comments and criticisms. Errors or differences that remain do so despite their best efforts. Locke R. McMurray rendered excellent research assistance.

I See John H. Langbein, Substantial Compliance with the Wills Act, 88 HARV. L. REV. 489 (1975).

${ }^{2}$ John H. Langbein \& Lawrence W. Waggoner, Reforming the Law of Gratuitous Transfers: The New Uniform Probate Code, 55 ALB. L. REV. 871, 873-74 (1992). Langbein is a member of the Joint Editorial Board for the Uniform Probate Code, which oversaw the revisions. Waggoner is Director of Research and Chief Reporter of the Joint Editorial Board and Reporter for the revised Article II of the Code. The Prefatory Note to the revised Article II also mentions the importance of "intentserving policies" in place of formalism. UNIF. PROB. CODE art. II prefatory note (1990).

${ }^{3}$ See, e.g., James Lindgren, The Fall of Formalism, 55 ALB. L. REv. 1009, 1010 (1992) (claiming the 1990 Uniform Probate Code reduces reliance on formalities and increases reliance on intent).

${ }^{4}$ See Roscoe Pound, The Theory of Judicial Decision, III, 36 HARV. L. REV. 940, 94752 (1923) (recognizing the tension between the just result and the legal result, and 
This Essay explores that tension. It examines the revisions to the law of wills proposed by the Uniform Probate Code and asks whether the formalism that the drafters wish to "cure" is an "anguished, pedantic cult of symbols wholly worthless and meaningless in themselves," "the effort to make sense of the lawyer's perception of an intelligible order, ${ }^{n 6}$ or simply "the extreme and therefore unfortunate manifestation of a fundamentally desirable characteristic." It suggests that the character of formalism derives from our collective judgment of what it accomplishes in different settings, and that its utility is similarly contingent on context. This Essay joins the long-standing discussion of formalism by Lon Fuller, Duncan Kennedy, Carol Rose, Frederick Schauer, Ernest Weinrib, and others, but from the bottom up, as it were-from the perspective of a body of law that, while perhaps low in raw intellectual sex appeal, nonetheless touches everyone who dies. ${ }^{8}$

arguing justice should be a judge's first concern before that of applying a rigid law); see also Duncan Kennedy, Form and Substance in Private Law Adjudication, 89 HARV. L. REV. 1685 (1976) [hereinafter Kennedy, Form and Substance] (examining the conflicts and similarities in the use of formalism and ad hoc decision-making in contract law); Duncan Kennedy, Legal Formality, 2 J. LEGAL STUD. 351 (1973) [hereinafter Kennedy, Legal Formality] (discussing the liberal theory of justice in terms of the model of formality). Kennedy recognized the commonality of interest and described Pound's article as "the first self-conscious general statement of principles for the choice of form, at least by an American." Kennedy, Form and Substance, supra, at 1702.

52 RUDOLPH VON JHERING, GEIST DES ROMISCHEN RECHTS AUF DEN VERSCHIEDENEN STUFEN SEINER ENTWICKLUNG 478-79 (1883), quoted in Kennedy, Legal Formality, supra note 4 , at $354-55$.

${ }^{6}$ Ernest J. Weinrib, Legal Formalism: On the Immanent Rationality of Law, 97 YALE L.J. 949, 951 (1988).

${ }^{7}$ Frederick Schauer, Formalism, 97 YALE L.J. 509, 548 (1988).

${ }^{8}$ The leading contributions to the discussion are Lon L. Fuller, Consideration and Form, 41 ColUM. L. REv. 799 (1941) (examining the policies behind legal formalities with respect to the common-law doctrine of consideration); Kennedy, Form and Substance, supra note 4; Kennedy, Legal Formality, supra note 4; Carol M. Rose, Crystals and Mud in Property Law, 40 STAN. L. REV. 577 (1988) (describing the transformation of "hard-edged" rules in property law into "muddied" doctrines); Schauer, supra note 7 (discussing the meaning of formalism and urging a rethinking of contemporary aversion to formalism); and Weinrib, supra note 6 . Other important participants include Lawrence M. Friedman, Law, Rules, and the Interpretation of Written Documents, $59 \mathrm{Nw}$. U. L. REV. 751 (1965) (focusing on rules relating to the interpretation of written documents, Friedman shows the relationship between the social and historical forces at work on legal rules); and Isaac Ehrlich \& Richard A. Posner, An Economic Analysis of Legal Rulemaking, 3 J. LEGAL STUD. 257 (1974) (arguing that the precision of the rule determines the economic efficiency of the legal process). 


\section{FORMALITIES AND REFORM}

The centerpiece of the 1990 Uniform Probate Code is the most significant change in what constitutes a will since enactment of the Statute of Frauds in 1677. For over three hundred years, wills have been defined by their formal qualities. The details have varied, but the essential formal requirements-writing, signature, and attestation-have remained constant and inviolate. These three formal requirements remain in a modified $\S 2-502$, but they are no longer essential. Indeed, one could say that they remain in form only. A new provision, $\S 2-503$, permits a court to dispense with the formalities if it is satisfied "that the decedent intended the document ... to constitute" his or her will. ${ }^{9}$

The significance of this change cannot be overstated. Wills have always been creatures of form rather than substance. A document that meets the formal requirements of the applicable Wills Act is a will. Whether or not a decedent intended a formally executed document to be his or her will has always been secondary to whether or not the document complied with the statutory formalities. Indeed, the issue of testamentary intent arises only when someone contesting the will questions whether the testator had sufficient mental capacity to make a will in the first place. Barring a contest, courts infer intent from compliance with form. Section

${ }^{9}$ UNIF. PROB. CODE $§ 2-503$ (1990). This section, Writings Intended as Wills, is worth quoting in full:

Although a document or writing added upon a document was not executed in compliance with Section 2-502, the document or writing is treated as if it had been executed in compliance with that section if the proponent of the document or writing establishes by clear and convincing evidence that the decedent intended the document or writing to constitute (i) the decedent's will, (ii) a partial or complete revocation of the will, (iii) an addition to or an alteration of the will, or (iv) a partial or complete revival of his [or her] formerly revoked will or of a formerly revoked portion of the will.

Id.

A critical adjunct to $\$ 2-503$ is $\$ 2-502$ (c), which provides that "[i]ntent that the document constitute the testator's will can be established by extrinsic evidence." Id. $\$ 2-502$ (c) (1990). This is the first time extrinsic evidence has been accepted to establish or interpret formally executed wills outside of the narrow area of resolving patent ambiguities. For the sake of simplicity, references in this Essay to the dispensing power of $\S 2-503$ will include the authorization of extrinsic evidence in $\S 2-502(c)$ that gives teeth to $\$ 2-503$.

The 1991 text of the Uniform Probate Code incorporates minor changes that do not alter any of the sections discussed in this Essay. As my subject is the 1990 revisions, I will cite to the 1990 text to avoid confusion. 
2-503, however, makes the testator's intent paramount and, more to the point, independent of form.

Section 2-503 is the most recent salvo in a long campaign against formalism in wills adjudication, the roots of which go back over fifty years. ${ }^{10}$ It is important to remember that the target of the campaign has always been formalism rather than the formalities themselves. The statutory requirements for formal wills serve useful ends. They take the vast array of testamentary things and channel them into a form that is readily recognizable as a will, thus easing the transfer of property at death. By imposing a standard form on testamentary writings, they enable probate courts to identify documents as wills solely on the basis of readily ascertainable formal criteria, thereby permitting probate to proceed in the vast majority of cases as a routine, bureaucratic process. ${ }^{11}$

The problem lies not with the formalities, but with judicial insistence on literal compliance with them. Was one of the attesting witnesses called from the room while the testator was in midsignature? If so, the will is invalid because it was not signed in the presence of both witnesses. ${ }^{12}$ Did the witnesses sign separately, the first one passing the second on the way out of the room? If so, the will is invalid because the witnesses did not sign in each other's presence. ${ }^{13}$ Did the attorney omit the attestation clause, although the witnesses signed a self-proving affidavit that they thought was an attestation clause, that looked like an attestation clause, and that was where the attestation clause would have been? If so, the will is invalid because not attested. ${ }^{14}$ Courts have routinely invalidated wills for minor defects in form even in uncontested cases and sometimes even while conceding-always ruefully, of course-that the document clearly represents the wishes and intent of the testator.

${ }^{10}$ The earliest criticisms were Ashbel G. Gulliver \& Catherine J. Tilson, Classification of Gratuitous Transfers, 51 YALE L.J. 1, 3 (1941) (formal requirements "should not be revered as ends in themselves, enthroning formality over frustrated intent"); and Philip Mechem, Why Not a Modern Wills Act? A Comment on the Wills Provisions of the Model Probate Code, 33 IowA L. REv. 501, 504 (1948) (claiming the Model Probate Code's "imposition of further formalities is likely to imperil meritorious wills"). The campaign languished, however, until Langbein took up the cause. See Langbein, supra note 1 .

${ }^{11}$ See Lawrence M. Friedman, The Law of the Living, the Law of the Dead: Property, Succession, and Society, 1966 WIS. L. REV. 340, 367-68; Fuller, supra note 8, at 801-03; Langbein, supra note 1, at 493-94.

${ }_{12}$ See In re Colling, [1972] 1 W.L.R. 1440, 1442-43 (Eng. Ch.).

${ }^{13}$ See In re Groffman, [1969] 1 W.L.R. 733, $737-79$ (Eng. P.).

${ }^{14}$ See Wich v. Fleming, 652 S.W.2d 353, 355 (Tex. 1983). 
This judicial rule of strict compliance with Wills Act formalities is what led Langbein to begin his call for reform with the charge that " $[t]$ he law of wills is notorious for its harsh and relentless formalism. ${ }^{n 15}$

Langbein rested his call on the proposition that "[t]he first principle of the law of wills is freedom of testation." 16 The principle that people should be able to devise their property as they wish, although deeply rooted in the common law, has always described an ideal rather than reality. Like its inter vivos cognate, "a man's home is his castle," it evokes images of independence and individualism derived from ownership of private property. In reality, of course, the autonomy of private property owners is sharply circumscribed-in life and in death. For the living, there are zoning rules, building codes, nuisance laws, environmental regulations; for the dead, there are estate taxes, homestead and family maintenance allowances, forced shares for surviving spouses and sometimes children-all reflecting political decisions to constrain private property in favor of some superseding value. All these limitations notwithstanding, courts and commentators alike make obeisance to free testation. The practical consequence of this deference is that the many rules that govern what constitutes a will and how it should be construed all purport to promote discovery of what the dearly departed intended.

Rules, however, sometimes assume lives of their own, particularly in bureaucratic systems such as probate. When they do-when courts refuse to countenance even minor slips in compliance-the administrative convenience of the formalities becomes the slavish adherence to form of formalism. Langbein offered an escape from the formalistic bind of strict compliance. He argued that the formalities are legitimate only insofar as they signify that functions deemed essential to the process have been fulfilled. Compliance with the formalities allows one to infer performance of the functions. ${ }^{17}$ If the formalities derive their meaning from the functions they serve, then, Langbein argued, courts should not stand on formality, but should instead accept substantial compliance

${ }^{15}$ Langbein, supra note 1, at 489.

${ }^{16} I d$. at 491.

${ }^{17}$ See id. at 491-98 (discussing four functions served by compliance with formalities). Langbein drew on Fuller, supra note 8, at 800-04, and Gulliver \& Tilson, supra note 10, at 5-13. The functions the formalities serve are variously identified as evidentiary, channeling, cautionary or ritual, and protective. 
with the formalities whenever they are satisfied that the document expresses the testator's intent and that its form, however imprecise, gives sufficient assurance that the purposes of the formalities have been served.

Langbein's proposal quickly became a staple of the reform literature. ${ }^{18}$ It did not, however, sweep the courts. Court after court refused to apply substantial compliance to save defectively executed wills, sometimes saying that to do so "would lead to confusion and uncertainty" ${ }^{19}$ or "unsettle the probate process, ${ }^{20}$ but more often rejecting it with little or no comment. ${ }^{21}$ Their refusal was so persistent that by the time a court bucked the trend and applied the doctrine, ${ }^{22}$ Langbein himself had switched his allegiance to the related solution that became $\$ 2-503 .{ }^{23}$

The "dispensing power" of $\S 2-503$ did not originate with the

${ }^{18}$ See, e.g., James Lindgren, Abolishing the Attestation Requirement for Wills, 68 N.C. L. REv. 541, 544 (1990) ("The question ... is whether the formality promotes the primary goal of our system of testation-effectuating the intent of the testator . . . ."); Bruce H. Mann, Self-Proving Affidavits and Formalism in Wills Adjudication, 63 WASH. U. L.Q. 39, 49 (1985) (questioning Texas courts' invalidation of wills for failure of formal requirements where "there was little or no question that the testator had intended the instrument to be a will"); J.K. Maxton, Execution of Wills: The Formalities Considered, 1 CANTERBURY L. REv. 393.(1982); J.G. Miller, Substantial Compliance and the Execution of Wills, 36 INT'L \& COMP. L.Q. 559, 56466 (1987) (discussing Langbein's substantial compliance doctrine); Charles I. Nelson \& Jeanne M. Starck, Formalities and Formalism: A Critical Look at the Execution of Wills, 6 PEPP. L. REV. 331, 355 (1979) ("There is something inherently fair about [Langbein's] approach which says that formalities are important but they are a tool and not a sword."). Langbein's proposal also earned him the title, which I am not sure I would describe as an honorific, of the "current 'dean' of the so-called 'functional school." C. Douglas Miller, Will Formality, Judicial Formalism, and Legislative Reform: An Examination of the New Uniform Probate Code "Harmless Error" Rule and the Movement Toward Amorphism, 43 FLA. L. REV. 599, 604 (1991).

${ }^{19}$ Hopkins v. Hopkins, 708 S.W.2d 31, 32 (Tex. Ct. App. 1986).

${ }^{20}$ In re Estate of Peters, 526 A.2d 1005, 1015 (N.J. 1987).

${ }^{21}$ See Flagle v. Martinelli, 360 N.E.2d 1269, 1272 (Ind. Ct. App. 1977) (stating that "the decedent's purported will . . . does not approach even substantial compliance"); Taylor v. Estate of Taylor, 770 P.2d 163, 166 (Utah Ct. App. 1989) (stating that even if the court "were to adopt a standard of substantial compliance" the will in question would be invalid).

${ }^{22}$ See In re Will of Ranney, 589 A.2d 1339, 1345 (N.J. 1991) (holding that will in which witnesses signed only the self-proving affidavit may still be in substantial compliance with formal attestation requirement in some circumstances). One earlier case applied substantial compliance to validate a defectively signed will, Estate of Kajut, 22 Pa. D. \& C.3d 123, 129-31, 136 (Orphans' Ct. 1981), but was settled before this departure could be tested by appellate review. See John H. Langbein, Excusing Harmless Errors in the Execution of Wills: A Report on Australia's Tranquil Revolution in Probate Law, 87 ColuM. L. REv. 1, 8 n.27 (1987).

${ }^{23}$ See Langbein, supra note 22 , at 51-54. 
Uniform Probate Code. While Langbein sought converts in the United States, two Australian states reformed their Wills Acts. One, Queensland, adopted Langbein's substantial compliance proposal. ${ }^{24}$ The other, South Australia, provided that documents that had not been executed with the requisite formalities could nonetheless be admitted to probate whenever the court was satisfied "that there can be no reasonable doubt that the deceased intended the document to constitute his will."25 The Queensland statute, in Langbein's words, "has been a flop, ${ }^{\text {"26 }}$ primarily because of judges who seem unable to relinquish the old certitude of literal compliance. ${ }^{27}$ The South Australia statute, on the other hand, has been a rousing success. Courts have applied it with impressive discrimination and liberality to admit formally noncomplying documents as wills. Other jurisdictions in Australia and Canada, and now the Uniform Probate Code, have copied it. ${ }^{28}$ Joining the train, which is still very much in the station, the American Law Institute has added its endorsement. ${ }^{29}$

${ }^{24}$ See Queensland Succession Act of 1981, § 9(a), Queensl. Stat. No. 69.

25 Wills Act Amendment Act (No. 2), 1975, §9, S. AUSTL. STAT. 366, 367 (amending Wills Act, 1936-1975, $\S 12(2), 8$ S. AUSTL. STAT. 665).

${ }^{26}$ Langbein, supra note 22 , at 1.

${ }^{27}$ For Langbein's criticism of the application of the statute, see Langbein, supra note 22 , at $41-45$.

${ }^{28}$ Langbein has analyzed the South Australia statute and the cases interpreting it in detail. See id. at 8-41. The few voices expressing reservations about the statute appear to have been ignored. See, e.g., William F. Ormiston, Formalities and Wills: $A$ Plea for Caution, 54 AUSTL. L.J. 451, 452-57 (1980) (arguing that the "formalities" of wills serve valid and necessary purposes and courts should be reluctant to allow substantial compliance to be sufficient); Simon N.L. Palk, Informal Wills: From Soldiers to Citizens, 5 ADEL. L. REv. 382, 396-401 (1976) (discussing the likely evidentiary problems of allowing courts to dispense with formal requirements and look to indicia of testamentary intent). For a discussion of the spread of the South Australia harmless error rule to other Australian states and Manitoba, see Langbein, supra note 22, at 45-48. The principal modification in the Uniform Probate Code version is one for which Langbein argued-that the decedent's intent be established by "clear and convincing evidence" rather than by a standard of "no reasonable doubt." Compare UNF. PROB. CODE § 2-503 (1990) with Wills Act § 12(2); see also Langbein, supra note 22, at 34-37 (discussing the standard of proof under $\S 12(2)$ of the Wills Act). Langbein's proposal echoes an earlier suggestion that plaintiffs in contract actions be permitted to prove the existence of an agreement within the Statute of Frauds by clear and convincing evidence rather than deciding the dispute by determining whether the writing itself meets the formal requirements of the Statute. See Joseph M. Perillo, The Statute of Frauds in the Light of the Functions and Dysfunctions of Form, 43 FORDHAM L. REV. 39, $74-77$ (1974).

${ }^{29}$ See ReSTATEMENT (SECOND) OF PROPERTY (DONATIVE TRANSFERS) $\$ 33.1 \mathrm{cmt} . \mathrm{g}$ (1990). Referring to the Australian reforms and to $\S 2-503$, comment $g$ urges legislative adoption of "a rule that excuses harmless errors in the execution of a will," 
The dispensing power operates more directly than substantial compliance. It forgoes the functional analysis of the latter and instead allows the proponent of a purported will to prove what courts now infer from compliance with the formalities-that the decedent intended the document to be a will. It thus redresses the evidentiary imbalance of the traditional rule-that compliance with the formalities raises a rebuttable presumption that the document is a will, while failure to comply creates a conclusive presumption that it is not-by treating both presumptions as rebuttable. The degree of compliance with the formalities may still be relevant, but only insofar as it bears on the decedent's intent, not on how closely it approximates full compliance. By subordinating the formalities and their functions to the testator's intent, the dispensing power frees courts from the fiction that the formalities are of equal weight and importance. As a consequence, courts can treat minor defects in execution as just that-minor defects that need not invalidate a will. With the dispensing power, wills would not be admitted to probate any less routinely than they are now. The important difference is that they could not be rejected as routinely.

The dispensing power also restores a measure of candor to the process of determining the formal sufficiency of testamentary writings. There has always been a hierarchy of formalities, which courts refuse to admit. Writing, for example, is indispensable. ${ }^{30}$ The testator's signature is also essential, but courts sometimes fudge what they will accept as a signature and where on the document it may appear. ${ }^{31}$ They are more liberal in what they will consider

or, failing that, judicial application of Langbein's substantial compliance doctrine. Id.

${ }^{30}$ The one exception, nuncupative wills, is tightly limited by various restrictions, one of which is that they must be reduced to writing within a short period of time. With regard to the requirement of Uniform Probate Code § 2-502(a)(1) that a will be "in writing," the comment states that "[a]ny reasonably permanent record is sufficient, " while citing a Wyoming case, Estate of Reed v. Holsledt, 672 P.2d 829, 833 (Wyo. 1983), that a tape-recorded will is not "in writing." Id. Indiana does permit videotapes of the execution ceremony to be admitted "as evidence of the proper execution of a will," but does not go so far as to accept videotape as the will itself. See IND. CODE ANN. \$ 29-1-5-3 (West Supp. 1993). For arguments that videotaped wills should be accepted as "in writing"-a prospect that any good traditionalist finds repugnant-see Gerry W. Beyer \& William R. Buckley, Videotape and the Probate Process: The Nexus Grows, 42 OKLA. L. REV. 43, 49-61 (1989); William R. Buckley \& Alfred W. Buckley, Videotaping Wills: A New Frontier in Estate Planning, 11 OHo N.U. L. REv. 271, 278-80 (1984). For a more modern, or at least more modish, view of nonprinted texts, see Ronald K.L. Collins \& David M. Skover, Paratexts, 44 STAN. L. REV. 509, $540-42$ (1992).

${ }^{31}$ See, e.g., Clark v. National Bank of Commerce, 802 S.W.2d 452, 454 (Ark. 1991) 
attestation, particularly in terms of what constitutes "presence." 32 Yet whenever courts stretch the definitions of signature and attestation, they always maintain that the variant they are accepting is compliance-not the functional equivalent, but actual compliance. Although often false, this stance is the only way that courts can soften the impact of a rule of strict compliance with every formality. The dispensing power eliminates the need for dissembling by interposing a notion of "harmless error" as a buffer between defective execution and intestacy.

The dispensing power of $\$ 2-503$ clearly has the potential to herald the fall of formalism in wills adjudication. ${ }^{33}$ Some commentators note this with trepidation, others with glee. ${ }^{34}$ Without question, simply by permitting courts to look outside the will for evidence of the testator's intent, $\$ 2-503$ weakens the grip of formalism. Nevertheless, the greatest contribution of the reform is to the fall of formalities, or, more accurately, to the fall, or at least decline, of a formality-a more modest, but still significant, contribution.

Attestation is the formal requirement that distinguishes wills from all other documents that transfer property-trusts, deeds, contracts, checks, insurance, pensions, and the like. It is also the formal requirement that is most complex, least intuitively obvious,

(deeming testator's signature to be at end although followed by nontestamentary language).

${ }_{32}$ See, e.g., Keely v. Moore, 196 U.S. 38, 43 (1904) (finding will valid even if signed "for some possible purpose as a certificate"); Payne v. Payne, 16 S.W. 1, 1 (Ark. 1891) (holding that the form of attestation is "immaterial"); Madden v. Cornett, 160 S.W.2d 607,610 (Ry. 1942) (stating that the fact that witness attached more writing than necessary did not invalidate his signature); Merrill v. Boal, 132 A. 721, 724 (R.I. 1926) (holding that witness's having signed as notary public did not affect validity of signature); Franks v. Chapman, 64 Tex. 159, 161 (1885) (finding will valid where clerk of court attached official certificate to signature); Ferguson v. Ferguson, 47 S.E.2d 346,353 (Va. 1948) (holding that notary public, regardless of self-perception of role, signed name as witness to will).

${ }^{38}$ The word "potential" must be emphasized. The provisions of the Uniform Probate Code are, of course, merely hortatory until enacted by state legislatures. To date, only two states, Montana and New Mexico, have enacted the revised Article II, and only Montana included $\S 2-503$ in its enactment. See Act of Apr. 23, 1993, ch. 494, 1993 Mont. Laws ("An Act generally revising the law concerning estates, wills, and donative transfers...”); Act of Apr. 3, 1993, ch. 174, 1993 N.M. Laws 1554, 1554 ("An Act relating to probate; amending, repealing, enacting, recompiling and reserving sections of the Uniform Probate Code").

${ }^{34}$ See Lydia A. Clougherty, Note, An Analysis of the National Advisory Committee on Uniform State Laws' Recommendation to Modify the Wills Act Formalities, 10 PROB. L.J. 283, 302 (1991) (expressing trepidation); see also Lindgren, supra note 3, at 1030-32 (expressing glee). 
and, consequently, easiest to violate. Not surprisingly, more wills are tossed from probate for defective attestation than for any other reason. Yet, by any functional analysis, attestation contributes little to the overall objective of assuring that the document represents the testator's intent.

The traditional justification for attestation is not an evidentiary one related to the substance of the will. Rather, it is that the presence of disinterested witnesses at the execution ceremony guards the testator against various nefarious acts, such as fraud or undue influence. ${ }^{35}$ In reality, attesting witnesses tend to be either family members, who are well-placed to commit the acts they are supposed to prevent, or comparative strangers in a lawyer's office or bank who sign when and where they are told and hardly see themselves as the testator's sentinels.

The fecklessness of attestation as a protective device is demonstrated by the routine acceptance of will substitutes-life insurance, pension accounts, joint accounts, and revocable trusts-which do not even contemplate attestation, and by the twenty-six states that accept holographic wills. Holographs, by definition, are unattested. Where allowed, they represent a legislative judgment that attestation is unnecessary, at least when the document meets other requirements-typically, that the instrument be handwritten, signed, and sometimes dated, by the testator. The key inquiry in virtually all holograph litigation is whether the testator wrote the document with testamentary intent. As a result, courts routinely inquire into the testator's intent in holographic wills, where there is no attestation, while they refuse to make the same inquiry into formal wills where there is substantively adequate, but formally imperfect, attestation. It is thus depressingly common to see courts within the same jurisdiction accept ludicrously informal writings as valid holographs while automatically rejecting elaborate wills drafted by attorneys and signed in formal execution ceremonies where the testator or witnesses happened to sign in the wrong place or in the wrong order. ${ }^{36}$

${ }^{35}$ For discussions of the protective function of attestation, see Gulliver \& Tilson, supra note 10, at 9-13; Langbein, supra note 1, at 496-97.

${ }^{36}$ Compare In re Button's Estate, 287 P. 964, 966 (Cal. 1930) (accepting rambling suicide note to ex-husband as holographic will) with Estate of Johnson v. Jackson Hosps., 320 P.2d 563, 566 (Cal. Dist. Ct. App. 1958) (rejecting will where testator failed to declare to witnesses that instrument they signed was his will); compare In re Kimmel's Estate, 123 A. 405, 406 (Pa. 1924) (accepting as holographic will chatty letter in which 30 words of 255 made testamentary noises) with In re Estate of Weiss, 279 A.2d 189, 192 ( $\mathrm{Pa} .1971$ ) (rejecting will where testator signed in the margin). 
All this makes attestation, as the formality that most often defeats the testator's intent, the most likely subject of the curative influence of the dispensing power. ${ }^{37}$ And, indeed, attestation comprises the largest category of formal defects cleansed by the South Australia act. ${ }^{38}$ This is not to suggest that the dispensing power should forgive all defects in attestation with equal alacrity. After all, the absence of attesting witnesses raises different and rather larger evidentiary questions about the testator's intent than do trivial failures of presence. What it does suggest is that, under $\S 2-503$, attestation will be treated as the weak formality it is.

Although clearly the most dramatic, $\$ 2-503$ is not the only revision to the Uniform Probate Code designed to cure "intentdefeating formalism." Holographic wills, for example, as noted above, have few formal requirements. Yet courts typically trip over them in the one situation in which the testator's intent is comparatively clear-where the document offered for probate is an unattested printed will form filled in and signed by the testator in his or her writing. The requirement that holographs be in the testator's handwriting sometimes has to contend with the troublesome presence of printed or typewritten matter on the document. When that happens, courts apply various rules to construe away the printed material and determine if what remains is a will by asking: Are the "material provisions" in the testator's handwriting, is the printed matter "mere surplusage," or did the testator "intend to incorporate" the printed portions into the handwritten provisions? ? $^{39}$

${ }^{37}$ Others have argued that the failures and weaknesses recounted in the text make an even better case for abolishing the attestation requirement altogether. See Lindgren, supra note 18 , at $542-43$.

${ }^{38}$ Langbein counted 46 applications of the $\S 12(2)$ dispensing power in 41 cases in South Australia. Twenty-three of the applications involved attestation defects, 11 involved testators' misplaced or missing signatures, and 12 involved alterations to the will. See Langbein, supra note 22, at 15 n.55.

${ }^{\text {s9 }}$ See, e.g., Estate of Johnson v. Johnson, 630 P.2d 1039, 1041 (Ariz. Ct. App. 1981) (not accepting an unattested printed will form for probate because material provisions not entirely in testator's handwriting); In re Thorn's Estate, 192 P. 19, 22 (Cal. 1920) (invalidating handwritten will because testator intended to incorporate name of property inserted with rubber stamp); In re Durlewanger's Estate, 107 P.2d 477, 478, 480-81 (Cal. Dist. Ct. App. 1940) (holding that where testator wrote the date "May 3, ${ }^{3} 38^{n}$ surrounding the printed number " 19 ," there was no evidence that the testator intended to incorporate the printed number as part of the date); In re Lowrance's Will, 155 S.E. 876, 878 (N.C. 1930) (striking printed words as surplusage and admitting the will to probate if handwritten remainder clearly expresses decedent's testamentary intent). See generally Gail B. Bird, Sleight of Handwriting: The Holographic 
Because of the comparative informality, not to mention the sheer quirkiness, of some of the writings offered for probate as holographic wills, the key inquiry in holograph litigation is whether the testator wrote the document with testamentary intent. Where the document is a printed will form, the best evidence of testamentary intent is the printed form itself-the very material that courts must construe away in the name of form. In the spirit of $\S 2-503$, a new provision, $\$ 2-502(\mathrm{c})$, recognizes this by providing that printed portions of the document can be used to establish that the testator intended the document to be his or her will. ${ }^{40}$ The "material portions" of the document must still be in the testator's handwriting, ${ }^{41}$ but even that minimal requirement seems unnecessary when the printed matter in question is the formulaic-and testamentary-language of a printed form will and, more particularly, when a wholly printed document signed by the testator but not attested can be admitted under $\$ 2-503 .{ }^{42}$

Other portions of $\S 2-502$ that govern the execution of witnessed wills loosen the formalities, but have little to do with formalism, at least formalism of the "intent-defeating" kind. One provision codifies a test that has not been in serious doubt for many decadesthe so-called "conscious presence" test, which permits someone else to sign for the testator in the testator's presence, even if the testator cannot see the person, as long as the testator is aware of the person's presence. ${ }^{43}$ Another provision permits the witnesses to sign the will "within a reasonable time after . . . witness[ing] either the [testator's] signing of the will ... or the testator's acknowledg-

Will in California, 32 HASTINGS L.J. 605, 633 (1981) (arguing for adoption of § 2-503 to alleviate problems of holographs); Kevin R. Natale, Note, A Survey, Analysis, and Evaluation of Holographic Will Statutes, 17 HOFSTRA L. REV. 159, 171-79 (1988) (arguing against a formalistic approach to interpreting holographic wills).

${ }^{40}$ Uniform Probate Code \$ 2-502(c) also permits extrinsic evidence to establish testamentary intent, thereby abandoning the hoary "four-corners" rule that required the testator's intent to be determined within the four corners of the document-a rule that, in any event, was more a statement of an ideal.

${ }^{41}$ UNIF. PROB. CODE § 2-502(b) (1990).

42 One reason for maintaining the "material portions" requirement for holographs is that wills proven under $\S 2-503$ must meet a higher standard of proof than those offered under $\$ 2-502$. This distinction rests on the functionalist assumption that the additional handwriting contained in the "material portions" is of sufficient evidentiary value to merit a lower evidentiary standard.

${ }^{43}$ UNIF. PROB. CODE § 2-502(a)(2) (1990). For more on the conscious presence test, see Verner F. Chaffin, Execution, Revocation, and Revalidation of Wills: A Critique of Existing Statutory Formalities, 11 GA. L. REv. 297, 318-22 (1977). 
ment of that signature or acknowledgment of the will. ${ }^{84}$ A "reasonable time" might even include not signing until after the testator dies. ${ }^{45}$

Another revision involves fighting formalism with form. Selfproving affidavits facilitate probate by creating sworn evidence of due execution. The testator and witnesses simply sign an affidavit declaring, in effect, that they executed the will in compliance with the requisite formalities-that is, that they affixed their signatures to the will in the manner prescribed. The affidavits permit wills to be admitted to probate without the burdensome inefficiency of summoning the attesting witnesses to reaffirm what they swore to in the affidavit and attested to in the attestation clause. As evidentiary devices, self-proving affidavits are elegantly simple-so much so that it may be malpractice for lawyers to draft wills without them. ${ }^{46}$ Sometimes, however, execution goes awry, and the testator or witnesses sign only the self-proving affidavit rather than the will or attestation clause. Given that self-proving affidavits closely resemble attestation clauses and are typically executed with the will and attached to it, there is scant reason not to accept the signatures to them as sufficient attestation. A perverse line of cases in Texas, however, held otherwise, until recently reversed by statute. ${ }^{47}$ Spurred by the sorry example of Texas, the revised

4 UNIF. PROB. CODE § 2-502(a)(3) (1990).

${ }^{15}$ The comment to $\S 2-502$ states: "[t]here is ... no requirement that the witnesses sign before the testator's death; in a given case, the reasonable-time requirement could be satisfied even if the witnesses sign after the testator's death." Id. $\S 2.502 \mathrm{cmt}$. Currently, even states that allow witnesses considerable latitude in when they can sign nonetheless require them to do so before the testator dies. See In re Estate of Royal, 826 P.2d 1236, 1237 (Colo. 1992); In re Estate of Mikeska, 362 N.W.2d 906, 910-11 (Mich. Ct. App. 1985); In re Estate of Flicker, 339 N.W.2d 914, 915 (Neb. 1983); Rogers v. Rogers, 691 P.2d 114, 115 (Or. Ct. App. 1984), review denied, 695 P.2d 1371 (Or. 1985). The New Jersey Supreme Court declined to accept a will that the witnesses had signed after the testator's death because too much time had elapsed, but conceded that " $[t]$ here may indeed be cases in which the affixation of witnesses' signatures after the testator's death would be reasonable." In re Estate of Peters, 526 A.2d 1005, 1013 (N.J. 1987).

${ }^{46}$ See Texas State Bar Comm. on Professional Ethics, Op. 360, reprinted in 35 TEX. B.J. 408, 408 (1972) ("An attorney preparing a will may be subject to criticism, but not discipline for not having used a self-proving affidavit on the will.").

${ }^{47}$ See Orrell v. Cochran, 695 S.W.2d 552, 552 (Tex. 1985); Wich v. Fleming, 652 S.W.2d 353, 354 (Tex. 1983); Boren v. Boren, 402 S.W.2d 728, 729-30 (Tex. 1966); Hopkins v. Hopkins, 708 S.W.2d 31, 33 (Tex. Ct. App. 1986); Shriners Hosps. for Crippled Children v. St. Jude's Children's Research Hosp., Inc., 629 S.W.2d 767, 767 (Tex. Ct. App. 1981); Rodgers v. Estate of King, 614 S.W.2d 896, 898 (Tex. Civ. App. 1981); Jones v. Jones, 630 S.W.2d 645, 647 (Tex. Civ. App. 1980); In re Estate of McDougal, 552 S.W.2d 587, 588 (Tex. Civ. App. 1977); McLeroy v. Douthit, 535 
Uniform Probate Code stipulates that "[a] signature affixed to a selfproving affidavit attached to a will is considered a signature affixed to the will, if necessary to prove the will's due execution, ${ }^{\mathbf{4 8}}$ thereby defining a formality with sufficient particularity to avert formalistic excess.

\section{FORMALISM AND WILLS}

The many references to "intent-defeating formalism" in the Code and commentary can easily lead one to overlook some basic questions: What does "formalism" mean in the context of wills adjudication? Do the reforms diminish it? If they do, is that good, bad, or indifferent?

The first thing one notices about formalism in the wills literature is that the word rarely appears unadorned. Formalism is "harsh and relentless,"49 "insistent," "unthinking," "51 "excessive." 52 As Ernest Weinrib observed, "[f]ormalism is like a heresy driven underground, whose tenets must be surmised from the derogatory comments of its detractors. ${ }^{n 3}$ When critics rail against formalism in wills adjudication, they have in mind neither the Wills Act formalities nor rules in general, but rules about the formalitiesspecifically, the rules mandating strict compliance and the intolerance of minor errors. The result is a rather narrow view of formalism that sees it as pertaining only to the initial determination of whether a document is a will and not to the more difficult question of how the document, once validated as a will, should be interpreted. Our understanding of formalism in wills will be enhanced if we reach beyond that narrow view and broaden our

S.W.2d 771, 773 (Tex. Civ. App. 1976), writ refused, 539 S.W.2d 351 (Tex. 1976); In $r e$ Estate of Pettingill, 508 S.W.2d 463, 465 (Tex. Civ. App. 1974); Cooper v. Liverman, 406 S.W.2d 927, 932 (Tex. Civ. App. 1966); McGrew v. Bartlett, 387 S.W.2d 702, 704-05 (Tex. Civ. App. 1965). Texas revised its wills statute in 1991 to say that "[a] signature on a self-proving affidavit is considered a signature to the will if necessary to prove that the will was signed by the testator or witnesses." TEx. PROB. CODE ANN. $§ 59(b)$ (West 1993). For a full discussion and critique, see Mann, supra note 18.

${ }^{18}$ UNIF. PROB. CODE $\$ 2-504$ (c) (1990). The Code does not require the use of selfproving affidavits, but, as noted, see supra note 46 and accompanying text, it is bad form for lawyers not to use them.

${ }^{49}$ Langbein, supra note 1 , at 489.

${ }^{50} \mathrm{Id}$.

${ }^{51}$ Mann, supra note 18 , at 49.

52 Id. at 67.

${ }^{53}$ Weinrib, supra note 6 , at 950 . 
perspective.

Definitions of formalism abound, ${ }^{54}$ but the one that is most useful in the wills context takes as its point of departure the interplay between rules and standards that Duncan Kennedy discussed in a pair of influential articles. ${ }^{55}$ When Kennedy argued that "[f]ormality consists in the attempt to accomplish substantively rational results ... through the substantively rational formulation and mechanical application of rules rather than directly through substantively rational decision processes, ${ }^{n 56}$ he was, in effect, describing the functional justification for formalities articulated by Fuller, Gulliver and Tilson, and Langbein, with a dollop of Max Weber's framework of formal and substantive rationality to identify the nature of the decision-making process. ${ }^{57}$ Rules are thus the formal realization of standards-not arbitrary substitutes, but surrogates for substantively rational decision-making that are themselves arrived at by substantively rational means.

If, for example, we take the testator's intent as a standard of wills adjudication-it certainly fits Kennedy's definition of standards as "substantive objectives of the legal order"58-then the functional analysis becomes an argument that the statutory formalities for wills are representations that facilitate implementing the testator's intent by substantively rational means. The formalities, although formally rational in the Weberian sense, are thus, in effect, representations of substantive rationality because of what they embody. The advantage of defining wills by their formal attributes, rather than by what evidence advances the standard of testamentary intent, is, of course, that formalities can be applied mechanically, while standards cannot.

${ }^{54}$ For a partial list of definitions with thumbnail sketches, see Schauer, supra note 7, at 510 \& n.1.

${ }^{55}$ See Kennedy, Form and Substance, supra note 4, at 1687-1713; Kennedy, Legal Formality, supra note 4, at 354-77.

${ }^{56}$ Kennedy, Legal Formality, supra note 4, at 358 (emphasis omitted).

${ }^{57}$ For Weber's most concise statement of his taxonomy of decision-making in adjudication and administration, see 2 MAX WEBER, ECONOMY AND SOCIETY: AN OUTLINE OF INTERPRETIVE SOCIOLOGY 653-58 (Guenther Ross \& Claus Wittich eds., 1978). For an accessible discussion of Weber's scheme, see ANTHONY T. KRONMAN, MAX WEBER 72-95 (1983).

${ }^{58}$ Kennedy, Form and Substance, supra note 4, at 1688 . Whether we should grant such a privileged status to the testamentary intent of dead people is a question of political philosophy with which I am not concerned here. Others have been, however. See, e.g., Mark L. Ascher, Curtailing Inherited Wealth, 89 MrcH. L. REV. 69, 73 (1990) (arguing that, as a general rule, "property rights should end at death"). I am simply dealing with the reality that we say that we should. 
The routinizing value of formalities are well-known. As Weber noted, "juridical formalism enables the legal system to operate like a technically rational machine. ${ }^{n 9}$ The formal requirements for wills enable probate to function as an administrative process rather than a judicial one in the crucial initial determination of whether or not a writing is a will. They impose a standard form on testamentary writings that, for the vast majority of documents that comply with it, relieves probate of the time-consuming and administratively inefficient burden of conducting an individual inquiry into the substantive issue of whether the decedent intended the document to be a will. Because "[s]ubstantively rational processes are disorderly, $" 60$ the massive volume of probate business and the inferior status of probate courts make such routinization essential. ${ }^{61}$

The routinization of probate by means of the formalities, however convenient or efficient, comes at a cost. Some wills are found formally wanting, and therefore invalid, despite the conceded clarity of their testamentary intent. One might argue that this is a trifling cost, whether measured against the social utility of administrative efficiency or by the social acceptability of intestate succession, which assures that property will pass within the family when wills fail. This would miss the point, however. Consider intestacy.

The statutory rules of intestate succession are default rules that approximate what most testators do in their wills anyway-provide for their immediate families. ${ }^{62}$ They represent legislative judgments of what people should do with their property. Intestacy thus has a normative status, which is underscored by the fact that remedial doctrines applied to wills to protect the testator's family,

592 WEBER, supra note 57 , at 811 .

${ }^{60}$ Kennedy, Legal Formality, supra note 4, at 364.

${ }^{61}$ For a more complete discussion of the relationship between the inferior status of probate courts and the routinization of probate business, see Mann, supra note 18, at 62-68. Schauer also notes that formalism "allocates power to some decisionmakers and away from others ... [and] therefore achieves its value when it is thought desirable to narrow the decisional opportunities and the decisional range of a certain class of decisionmakers." Schauer, supra note 7, at 544. Schauer develops this argument at length in FREDERICK SCHAUER, PLAYING BY THE RULES: A PHILOSOPHICAL EXAMINATION OF RULE-BASED DECISION-MAKING IN LAW AND IN LIFE 135-66 (1991) [hereinafter SCHAUER, PLAYING BY THE RULES].

${ }^{62}$ Langbein discusses the "backstopping" effect of intestate distribution statutes. See Langbein, supra note 1, at 499-501 (noting that the "backstopping" effect allows rigid enforcement of formalities). For a good general discussion of default rules, see Ian Ayres \& Robert Gertner, Filling Gaps in Incomplete Contracts: An Economic Theory of Default Rules, 99 YALE L.J. 87 (1989). 
such as forced shares for the surviving spouse and pretermitted children, operate by substituting some approximation of what the protected parties would have received had their decedent died intestate. Indeed, one occasionally glimpses a belief that intestacy should have a privileged status, as when the Supreme Court of California declared that " $[\mathrm{i}] \mathrm{n}$ the absence of any will, the law makes a wise, liberal, and beneficent distribution of the dead man's estate; so wise, indeed, that the policy of permitting wills at all is often gravely questioned. ${ }^{.63}$

The presumptive fairness of intestate distribution is irrelevant, however. If judges claim that the testator's intent is the standard, and if in individual cases of formal noncompliance they concede that the testator's intent is nonetheless clear, then to sacrifice the individual case to the ideal of formal uniformity is, to the sacrificial legatee, arbitrary, however just-or at least justifiable-it may be in terms of administrative efficiency and however fair intestate succession might be in general. ${ }^{64}$

It is precisely because the consequence of formal insufficiencyintestacy-is so manifestly what a testator does not intend that the attack on formalism in wills adjudication focuses so narrowly on what is a will. Formalistic application of the formalities is, in effect, the easy case. The attempt to leave a will, even if formally deficient, is at least some evidence, and often considerable evidence, of the underlying standard of testamentary intent. The "crystalline" nature of the formalities, to borrow Carol Rose's imagery, ${ }^{65}$ invites "muddying up" by the failure of noncompliance to blot out all evidence of the testator's intent. When that evidence remains, however, it seems only fair to say that we should weigh it and give effect to the testator's intent it proves.

It diminishes formalism, however, to regard it as simply the mechanical application of a few formalities. If that were all there were to it, the dispensing power of the new Uniform Probate Code

${ }^{63}$ In re Walker's Estate, 42 P. 815, 818 (Cal. 1895). The court modified its opinion on rehearing by deleting the quoted sentence and a similar one. See In re Walker's Estate, 42 P. 1082 (Cal. 1896) (per curiam). Some cases apply a presumption in favor of avoiding intestacy. See, e.g., In re Silva's Estate, 145 P. 1015, 1016 (Cal. 1915) ("A will is always to be interpreted so as to prevent intestacy if such interpretation is reasonably possible."); In re Buechley's Estate, 128 A. 730, 731 (Pa. 1925) ("[A] construction [of a will] should be adopted that avoids intestacy.").

${ }^{64}$ On the arbitrariness of rule application, see Kennedy, Legal Formality, supra note 4 , at 364 .

${ }^{65}$ See Rose, supra note 8, at 577 (referring to the "hard-edged rules" of property law as "crystals"). 
would eliminate formalism from wills adjudication entirely and the "problem" of formalism, if such it is, would be solved. If, however, we take a broader view and define formalism as the mechanical application of rules or, broader yet, as decision-making according to rule without regard for the individual case, then we can see that formalism flourishes even in the revised Code.

It clearly flourishes in intestate succession. The new availability of the dispensing power to remove formalistic obstacles to the testator's intent underscores the absence of any similar dispensation in intestacy, where the default rules remain as invariable as the formal requirements themselves were. The rules of intestate succession are "untailored" default rules that supply a single, off-therack standard to all intestate estates. ${ }^{66}$ One size fits all, even if evidence of the decedent's preference for a different size exists that is as persuasive as evidence of the testator's intent now permitted under $\S 2-503 .{ }^{67}$ There are compelling administrative reasons why this should be so. For example, what a decedent intended is harder to prove when there is no written document to narrow the inquiry. Moreover, the possibility of an individual inquiry into the dispositional wishes of everyone who dies is a bureaucratic nightmare. Compelling or not, the fact remains that while the formalism of wills formalities and the formalism of the default rules once presented a curious, but nonetheless real, kind of symmetry between testacy and intestacy, they no longer do. The resulting imbalance underscores the essential formalism of the rules of intestate succession.

That formalism is not diminished by the continued tinkering with the rules, making them ever more precise, such as the fine distinctions that now determine the intestate share of a surviving spouse. ${ }^{68}$ To be sure, ever-more-specific rules may approximate standards and thus produce more "just" results in individual cases. As long as their application is invariable, however, they remain

\footnotetext{
${ }^{66}$ On the distinction between "tailored" and "untailored" default rules, see Ayres \& Gertner, supra note 62, at 91-93.

${ }^{67}$ This would be the case if, for example, the decedent had left a tape-recorded or videotaped "will," neither of which, although perhaps highly indicative of the decedent's intent, are admissible to probate as a will, nor would their existence would not alter the pattern of intestate distribution either.

${ }^{68}$ See UNIF. PROB. CODE § 2-102 (1990); Lawrence W. Waggoner, Spousal Rights in Our Multiple-Marriage Society: The Revised Uniform Probate Code, 26 REAL PROP. PROB. \& TR. J. 683, 701-14 (1992) (providing a detailed analysis of Uniform Probate Code $\S 2-102$ ).
} 
rules, formalistically applied. ${ }^{69}$ Moreover, default rules necessarily have a certain disembodied quality, which stems from their justification in terms of presumed general or majoritarian intent rather than individual intent. The sense of disembodiment increases when the justification changes, as it did between the 1969 and 1990 versions of the Uniform Probate Code.

The introductory comment to Part 1 of Article II of the 1969 Code-the part on intestate succession-states that "[ $t]$ he Code attempts to reflect the normal desire of the owner of wealth as to disposition of his property at death, and for this purpose the prevailing patterns in wills are useful in determining what the owner who fails to execute a will would probably want."70 For default purposes, it certainly seems reasonable to infer that people who fail to leave valid wills have the same dispositional intent as those who do and construct the rules of intestate succession accordingly. Testators overwhelmingly provide for their immediate families, and so does intestate distribution. ${ }^{71}$ The 1990 revisions to the Uniform

${ }^{69}$ See SCHAuer, Playing by tHe RULes, supra note 61 , at 82-84.

${ }^{70}$ UNIF. PROB. CODE art. II, pt. 1 gen. cmt. (1969).

"1 The limited empirical research that has been done on testation indicates that testators typically give all of their property to their immediate family, usually the surviving spouse, although not necessarily outright. See, e.g., CAROLE SHAMMAS ET AL., INHERTTANCE IN AMERICA FROM COLONIAL TIMES to THE PRESENT 179-206 (1987) (discussing how estate taxes, government social programs, and the women's movement have impacted estate planning); MARVIN B. SUSSMAN ET AL., THE FAMILY AND INHERITANCE $125(1970)$ (stating that "[n]early 90 per cent of the decedent testators willed their entire estates to their spouses... where the spouse was the only survivor"); Olin L. Browder, Jr., Recent Patterns of Testate Succession in the United States and England, 67 MICH. L. REV. 1303, 1308 (1969) (noting that only six out of the 54 wills surveyed bequeathed anything to anyone besides the spouse and children); Allison Dunham, The Method, Process, and Frequency of Wealth Transmission at Death, 30 U. CHI. L. REV. 241, 252 (1963) (stating that where deceased was survived by spouse and children, all the testators left everything to the spouse). The few attempts to survey living property owners about their intestate preferences point to the same conclusion. See Contemporary Studies Project, A Comparison of Iowans' Dispositive Preferences with Selected Provisions of the Iowa and Uniform Probate Codes, 63 IowA L. REV. 1041, 1082 (1978) (supporting the disbursement of most of the estate to the spouse); Mary L. Fellows et al., Public Attitudes About Property Distribution at Death and Intestate Succession Laws in the United States, 1978 AM. B. FoUND. RES. J. 319, 386-87 (concluding that modern intestacy statute should provide spouse with entire estate in preference to other relatives); Joel R. Glucksman, Comment, Intestate Succession in New Jersey: Does It Conform to Popular Expectations?, 12 COLUM.J.L. \&c Soc. PrOBS. 253, 278 (1976) (finding that $80 \%$ of "testators gave their entire estates to their spouses"). For a different approach to the problem, which nonetheless arrives at the same place, see John H. Beckstrom, Sociobiology and Intestate Wealth Transfers, 76 Nw. U. L. REv. 216, 235-36 (1981) (using sociobiological theory to explain the preference for giving everything to spouses). Mary Ann Glendon ascribes the increasing inheritance rights 
Probate Code made only modest alterations in the details of intestate succession, but the justification has changed. Rather than invoke what the intestate decedent "would probably want," the introductory comment now talks about "fine tuning the various sections and bringing them into line with developing public policy. "72 To be sure, the rules do not lose their previous ties to the inferred intent of the decedent simply because the drafters offer a different justification. The change does, however, represent a telling, albeit tacit and doubtless unintended, uncoupling of rule and intent at the same time that the Code reattaches them when the decedent leaves a will. That uncoupling makes application of the rules of intestate succession formalistic-not bad, but formalistic.

The uncoupling of rule and intent also appears in the construction and application of wills, most clearly in provisions of the Uniform Probate Code that apply contrary to the stated intent of the testator. The most dramatic example is the elective share, which gives surviving spouses a portion of their deceased spouses' estates regardless of any directions in the will to the contrary. The common law has, of course, always accepted the principle that property-owning spouses should not be permitted to leave their surviving partners penniless. Dower was at least a small palliative for widows, who, because of the legal disabilities of married women, could never hold title to any of the marital property in their own names. Around the turn of the twentieth century, American legislatures began to replace the common-law estate of dower with a statutory right in the widow-gender neutrality is a recent gloss-to upset her husband's testamentary applecart, as it were, and to elect to take a statutory share in place of whatever her husband had given

of the surviving spouse to "the gradual attenuation of legal bonds among family members outside the conjugal unit of husband, wife, and children." MARY ANN Glendon, THE TRANSFORMATION OF FAMILy LAW: State, LAW, AND FAMILY IN THE UNITED STATES AND WESTERN EUROPE 238 (1989).

${ }^{72}$ Compare UNIF. PROB. CODE art. II, pt. 1 gen. cmt. (1990) with id. art. II, pt. 1 gen. cmt. (1969). Both comments refer to providing "suitable rules" for "the person of modest means who relies on the estate plan provided by law." UNIF. PROB. CODE art. II, pt. 1 gen. cmt. (1990); id. art. II, pt. 1 gen. cmt. (1969). This fig leaf of a justification is inherently improbable in light of the finding of one empirical study in which none of the respondents who did not have wills attributed their testamentary nakedness to satisfaction with the intestate distribution statute of their state-most (63.6\%) cited laziness. Moreover, of the 70\% of the respondents who said that they knew how their estates would be distributed by intestacy, fewer than half (44.6\%) were even close. See Fellows et al., supra note 71, at 339-40. In the hierarchy of daily activities, taking out the garbage is considerably more pressing than writing a will. Small wonder, then, that most people die intestate. 
her by will. These state elective-share schemes attained varying degrees of complexity in response to real or imagined attempts by angry, misogynist, or simply indifferent husbands to evade the statutory minimums. Although once dismissed-wrongly and a bit cavalierly-as "a solution in search of a problem," the elective share has become in the current Uniform Probate Code an issue of gender equality designed explicitly to implement the partnership theory of marriage. ${ }^{74}$ As codified and revised in \$\$ 2-201 to 2-207, the elective share is a complex set of rules that makes fine adjustments according to objective, formally ascertainable criteria-the nature of the property, the form of its ownership, the date and form of any transfer, the duration of the marriage, the relative wealth of each spouse, and the like. The details, for our purposes, are unimportant. What matters is that once the surviving spouse decides to exercise the statutory right of election, the elective share operates automatically to counter the testamentary intent of one spouse to disinherit the other.

The formalism of the elective share is explicit in its disregard of the testator's intent. Formalism also inheres somewhat less obviously, but still tellingly, in other remedial provisions of the Uniform Probate Code that fill in gaps in a will by imputing a particular intent to the testator. Rules are not formalistic only when they apply in the face of a contrary intent. They are also formalistic when they apply on the basis of a presumed intent that bears no necessary relationship to the individual case at hand. The degree of formalism may not be as great, but it is still worthy of the name.

Gaps can arise in wills for three reasons-the will fails to dispose of all the testator's property, a beneficiary named in the will dies before the testator, or property bequeathed in the will is no longer

${ }^{73}$ Sheldon J. Plager, The Spouse's Nonbarrable Share: A Solution in Search of a Problem, 33 U. CHI. L. REV. 681, 681 (1966); see also Elias Clark, The Recapture of Testamentary Substitutes to Preserve the Spouse's Elective Share: An Appraisal of Recent Statutory Reforms, 2 CONN. L. REV. 513, 514 (1970) (stating that the elective share situation "arises with such infrequency as to render the problem of little practical consequence").

${ }^{74}$ See UNIF. PROB. CODE, art. II, pt. 2 gen. cmt. (1990) (stating that the purpose of revisions to elective-share law is to adopt the "contemporary view of marriage as an economic partnership"); Langbein \& Waggoner, supra note 2, at 874 (increasing spousal share of estate from one-third to one-half "bespeak[s] a policy to implement the partnership theory of marriage"). For a full discussion of what became the revised elective-share provisions of the current Uniform Probate Code, see John $\mathrm{H}$. Langbein \& Lawrence W. Waggoner, Redesigning the Spouse's Forced Share, 22 REAL PROP. PROB. \& TR. J. 303 (1987); Waggoner, supra note 68, at 715-51. 
in the estate when the testator dies. Statutory rules exist to fill each of these gaps-intestate succession, antilapse, and ademption, respectively. We have already seen the formalism of intestate succession, which rests in part on the presumed intent of decedents and in part on public policy. The formalism of antilapse and ademption also rest on the presumed intent of decedents, but whereas the presumed intent that underlies intestate succession is derived by analogy from the actual intent of testators, the presumed intent that underlies the other two is less demonstrable. This does not make them wrong. It simply illustrates the separation of rule and intent that defines formalism.

One of the many disabling consequences of death is that beneficiaries that die before their testators lose their bequests, which lapse and pass by default under a residuary clause or, if there is none, by intestacy. Antilapse statutes remedy the supposed "wrong" of this result by saving the bequests to certain dead legatees and giving them instead to their descendants. In a world of perfect estate planning, antilapse statutes would be unnecessarytestators would foresee all possibilities and draft their wills accordingly, or at the very least they would rush to amend their wills when a beneficiary died. In the imperfect world of reality, antilapse statutes stand ready to fill the gaps that inevitably intrude. ${ }^{75}$ How they fill them rests on the assumption that if testators had thought about the problem, they would have preferred that the bequest be preserved for the benefit of the beneficiary's family, at least where the beneficiary was a close relative of the testator. ${ }^{76}$ In point of fact, however, antilapse statutes swing into action only when testators never considered the problem at all. When testators do not themselves make alternate gifts of bequests that fail, there is little evidence as to whether they would prefer the bequests to lapse or not. ${ }^{77}$ In any given case, it may be at least as likely that the

${ }^{75}$ For good general discussions of antilapse statutes, see Susan F. French, Antilapse Statutes Are Blunt Instruments: A Blueprint for Reform, 37 HASTINGs L.J. 335 (1985); Patricia J. Roberts, Lapse Statutes: Recurring Construction Problems, 37 EMORY L.J. 323 (1988).

${ }^{76}$ A bare majority of antilapse statutes limit the class of protected beneficiaries to, at most, the testator's grandparents and their issue. See French, supra note 75, at 34445,375 . This limitation to reasonably close relatives is similar to the limits of many intestate succession statutes, beyond which the decedent's property escheats to the state.

${ }^{77}$ Some writers invoke an "instinctive preference for representation among descendants" and point to its centuries-deep origins in the common-law rules of descent of real property. Edward C. Halbach, Jr. \& Lawrence W. Waggoner, The 
testator would have wanted one as the other. With the single exception of New Jersey, however, courts do not inquire into what testators would have wanted. ${ }^{78}$ Instead, the only room for testators' actual intent is as a negative-antilapse statutes are rules of construction that apply unless testators intend that they do not. Although one could construct an antilapse statute that elicited an approximation of testators' likely intent by a finely 'contextualized analysis of family relations and the overall estate plan, no state has. ${ }^{79}$ Indeed, the revised antilapse provision of the Uniform Probate Code, $\$ 2-603$, slightly increases the weight of evidence necessary to prove a testator's intent that the antilapse statute not apply. ${ }^{80}$ Antilapse statutes are thus default rules that apply

UPC's New Survivorship and Antilapse Provisions, 55 ALB. L. REv. 1091, 1101-02 \& nn.46, 48 (1992). However instinctive this preference might be when the lapsed bequest is to a child or grandchild of the testator, it is not at all clear that the instinct is as compelling when the lapsed bequest is to a collateral relative. See Lawrence H. Averill, Jr., An Eclectic History and Analysis of the 1990 Uniform Probate Code, 55 ALB. L. REv. 891, 923-24 (1992); Langbein \& Waggoner, supra note 2, at 888 n.38.

${ }^{78}$ In cases of potential lapse, courts in New Jersey look to extrinsic evidence, if necessary, to determine the testator's "probable intent" as to what should be done with the property. See In re Estate of Burke, 222 A.2d 273, 280 (N.J. 1966) (determining intent based on "the entire will, competent extrinsic evidence, and common human impulses"); In re Estate of Cook, 206 A.2d 865, 867 (N.J. 1965) (stating that the court will consider all of the surrounding facts and circumstances); Fidelity Union Trust Co. v. Robert, 178 A.2d 185, 187-89 (N.J. 1962) (discussing the "probable intent" doctrine).

${ }^{79}$ The Pennsylvania antilapse statute does take a small step in this direction by assuming that a testator would not want to save a bequest to a brother or sister, or to a niece or nephew, if the consequence of letting it lapse would be that property would pass to the testator's own spouse or issue. See 20 PA. Cons. STAT. ANN. $\$ 2514(9)$ (1975). Susan French has proposed an antilapse statute that does take into account the testator's family relations and overall estate plan. See French, supra note 75, at 371-73 (detailing the provisions of the proposed statute).

${ }^{80}$ Antilapse statutes are rules of construction that do not apply when the testator has expressed a contrary intent. Many estate planners attach words of survival to bequests in the apparent belief that they will automatically bar application of the antilapse statute to save the bequest. The efficacy of the words of survival, however, is open to question, given the amount of litigation over them. The revised Code states expressly that "words of survivorship, such as in a devise to an individual 'if he survives me,' or in a devise to 'my surviving children,' are not, in the absence of additional evidence, a sufficient indication of an intent contrary to the application of this section." UNIF. PROB. CODE § 2-603(b)(3) (1990). Some commentators have sharply criticized this change. See Mark L. Ascher, The 1990 Uniform Probate Code: Older and Better, or More Like the Internal Revenue Code?, 77 MINN. L. REV. 639, 649-57 (1993) (expressing "strong reservations" about the changes in the antilapse provisions); Martin D. Begleiter, Article II of the Uniform Probate Code and the Malpractice Revolution, 59 TENN. L. REV. 101, 126-30 (1991) (arguing that the new antilapse provisions will increase the likelihood of malpractice litigation). Others, of course, disagree. See Mary L. Fellows, Traveling the Road of Probate Reform: Finding 
mechanically with little or no regard for what individual testators might have intended. Weak formalism, perhaps, but still formalism.

Traditionally, if a testator dies no longer owning property that he or she has specifically devised in the will, the bequest is adeemed-the beneficiary takes nothing. ${ }^{81}$ Whether or not the testator intended that result is irrelevant. At first glance, and, for some, at subsequent glances as well, this seems to be an intuitively obvious result-how can a beneficiary take a bequest of something that the testator no longer owned? Rules, of course, cry out for exceptions when confronted with sympathetic or ingeniously argued cases. What if the specifically devised property was destroyed in the accident that killed the testator, but there are insurance proceeds to be distributed? What if the testator had sold a specifically devised item and replaced it with a newer or older or cheaper or more expensive version, or with something else entirely? What if it was not the testator who sold the specifically devised property, but a guardian or conservator? Barred from considering extrinsic evidence of the testator's intent, courts nonetheless fashioned various escape devices to avoid ademption-saying that a bequest is not specific and therefore not adeemed, or that mere changes in form do not trigger ademption, or that wills "speak" only upon the testator's death and pass whatever items approximate those present when the will was executed. ${ }^{82}$ The escape devices softened the supposedly "harsh" formalism of the identity theory of ademption, although not by referring to the intent of the individual testator

the Way to Your Will (A Response to Professor Ascher), 77 MINN. L. REv. 659, 674-80 (1993) (criticizing Ascher's view of survivorship language); Halbach \& Waggoner, supra note 77, at 1104-15 (arguing that "the insertion of words of survivorship [into a will] provides neither objective evidence that a conversation about the antilapse statute took place nor even objective evidence that the client was put on notice to

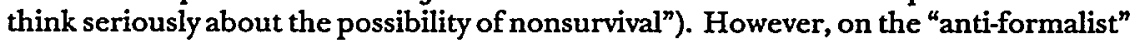
side of the scales, the revised Code also admits extrinsic evidence to rebut the rules of construction. See UNIF. PROB. CODE $\$ 2-601 \mathrm{cmt}$. (1990). In any event, it is hard to quarrel with the reason behind the change, which is to force lawyers to discuss the possibility of lapse directly with their clients and determine what each client would want done if beneficiaries died in the wrong order. See Halbach \& Waggoner, supra note 77, at 1102-04, 1109-15.

${ }^{81}$ Strictly speaking, it is adeemed by extinction. Ademption by satisfaction is another, less odorous, kettle of fish. On ademption generally, see THOMAS E. ATKINSON, HANDBOOK OF THE LAW OF WILLS § 134 (2d ed. 1953).

${ }^{82}$ For discussions of classification and the change-in-form and time-of-death constructions, see Gregory S. Alexander, Ademption and the Domain of Formality in Wills Law, 55 ALB. L. REV. 1067, 1073-75 (1992). When a bequest is not adeemed, the legatee receives its value or the object that replaced it. 
whose bequest it was-an intent that, after all, the testator had left unexpressed and, perhaps, unformed. Ademption, itself a gapfilling remedy, thus spawned its own remedial devices.

The Uniform Probate Code before 1990 accepted the traditional rule, modified by four limited exceptions. ${ }^{83}$ The ademption rule of the revised Code, $\S 2-606$, changes field entirely. The formal default rule now provides that specific bequests are not adeemed "unless the facts and circumstances indicate that ademption of the devise was intended by the testator or ademption of the devise is consistent with the testator's manifested plan of distribution. ${ }^{\text {"84 }}$ Commentators refer to this as "the intent-serving nonademption rule, ${ }^{n 85}$ and the comment to $\S 2-606$ proclaims that ${ }^{~}[t]$ he major import of the revisions of this section is to adopt the 'intent' theory. ${ }^{866}$ Yet the initial default rule is every bit as formalistic as the one it replaced. Both rest on the presumed intent of the testator, but it is a suppositious intent with no empirical foundation. There is no particular reason to believe that one position comports with the intent of most testators any better than the other, although that has not stopped commentators from arguing the point. ${ }^{87}$ This disjunction between rule and intent should not obscure the fact that the revised rules of ademption are, on the whole, less formalistic than before. It is worth noting, however, that even attempts to weaken formalism in the law of wills must accept formalistic default rules as the starting points from which they vary.

${ }^{83}$ See UNIF. PROB. CODE § 2-608 (1969). The exceptions covered situations where the specifically devised property had been sold before the testator's death and part of the purchase price remained unpaid, where the property had been taken by government action and a condemnation award was due, where there were fire or casualty insurance proceeds on the property, and where the testator had received property upon or in lieu of foreclosure of the security for a specifically devised obligation.

\& UNIF. Prob. CODE § 2-606(a)(6) (1990).

${ }^{85}$ Langbein \& Waggoner, supra note 2 , at 874.

${ }^{86}$ UNIF. PROB. CODE $\$ 2-606 \mathrm{cmt}$. (1990).

${ }^{87}$ Compare Alexander, supra note 82 , at 1068,1089 (stating that the identity theory, which would adeem by extinction any specific devise that is not part of the estate at death, is not consistent with testators' expectations) and Fellows, supra note 80 , at 672 (arguing that a specific bequest does not necessarily indicate "that the testator intended to embrace the identity theory") with Ascher, supra note 80, at 644 (arguing that a "specific bequest generally reflects a testator's wish that a particular item pass to a particular individual"). 


\section{FORMALISM: THE GOOD, THE BAD, AND THE INDIFFERENT}

When critics attack formalism in the law of wills, they tacitly distinguish between "good" formalism and "bad" formalism. "Bad" formalism frustrates a testator's benign intent. It is the "punctiliousness that produces injustice" 88 of strict compliance with the formalities of execution. Critics never discuss, let alone attack, the "good" formalism that frustrates the testator's intent when public policy identifies the intent as malign, as when testators attempt to disinherit their wives or husbands. Yet, both involve the mechanical application of rules to produce results that are contrary to what the testator intended. If formalism is objectionable in the one case, it should also be objectionable in the other-unless, of course, formalism is not the problem at all.

The formalism of the Wills Act formalities is, for want of a better description, a kind of procedural formalism. It serves a gatekeeping function by governing the initial determination of whether people die testate or intestate. It purports to be value neutral in that it directs judges to apply the formal criteria objectively without being swayed by how their decisions will affect individual legatees and heirs. Substantive consequences are merely incidental to the formal decisions and not at all constituted by them. The fallacy of this is what prompts criticism. Judges, who are bound by the formalism of the formalities, nonetheless often let the individual case intrude, as when they bend the formalities for a sympathetic legatee who would otherwise lose out or refuse to bend them for an equally sympathetic legatee who has intestate succession as a fallback. Commentators, who are not so bound, ask openly why the individual case should not intrude when there is strong evidence of the testator's intent. When testators attempt to contract around the default rules of intestacy, why should they be prevented from doing so by the formalistic application of rules that are meant to assist them? Formalism of the formalities is thus "bad" because its purported neutrality sweeps too broadly, making no distinction between near misses and thorough failures.

The formalism of rules such as the elective share is, by way of contrast, a formalism of substance, in which the rule exists to further a specific social end. There is no pretense of neutrality. Indeed, one imagines elective-share statutes wearing their frustration of the testator's intent proudly. Most elective-share provisions

${ }^{88}$ Mann, supra note 18 , at 68 . Mea culpa. 
operate rather bluntly, but the revised Uniform Probate Code individualizes the remedy by factoring in the length of the marriage and the amount of property owned by the surviving spouse-in short, by refining the formal rule. The elective-share rule operates mechanically, but its particularity and the laudability of its end combine to make the formalism of it and similar remedial rules "good" formalism. That said, one never sees it discussed as such, or even described as formalistic at all. Perhaps, when the rule is itself the reform, categorization seems churlish.

Then there is the formalism, however weak, of other remedial rules, such as antilapse and ademption. If we characterize formalism by our approval or disapproval of what it accomplishes, the formalism of these rules is "indifferent" formalism. The default rules in antilapse and ademption have no particular social utility. They do not.raise issues of fairness or justice. Indeed, there is little reason why anyone should care whether or not bequests lapse or are adeemed, unless, of course, one stands to gain or lose by the decision. The gaps that antilapse and ademption rules fill must be filled somehow, but when the social stakes are so low, one rule is probably as good as another. ${ }^{89}$

The key to understanding these widely divergent reactions may lie in the inherent conservatism of formalism. "Rules force the future into the categories of the past," as one scholar observed. ${ }^{90}$ They confine the discretion of judges and other decision-makers within predetermined bounds by limiting what is relevant to what has been deemed relevant before. What such rule-bound decisionmaking sacrifices in flexibility and adaptability, it gains in stability, certainty, and predictability. ${ }^{91}$

The Wills Act formalities are stereotypical "categories of the past, ${ }^{n 92}$ as their provenance makes so clear. The formalistic requirement of strict compliance prevents courts from reconsidering the continued relevance of the categories and from recognizing that formalities can lose their substantive meaning, as attestation has. This failure mattered little when there were no alternatives to wills for property owners who wanted to control the disposition of their

${ }^{89}$ See, e.g., UNIF. PROB. CODE $\$ 2-606 \mathrm{cmt}$. (1990) (stating that the presumption against ademption is only a "mild" one).

${ }^{90}$ Schauer, supra note 7, at 542.

${ }^{91}$ For a good discussion of the stabilizing effects of limiting decision-making authority, see id. at 538-44; see also SCHAUER, PLAYING BY THE RULES, supra note 61, at $137-45$.

${ }^{92}$ Schauer, supra note 7, at 542. 
property at death, but who did not have enough surplus wealth to create trusts while they were alive. The law of wills could thus persist in its formalistic splendor as the sole unchallenged alternative to intestacy.

It is significant that criticism of wills formalism arose only when other devices for passing property at death began to challenge the monopoly of wills. Will substitutes such as life insurance, pension accounts, joint accounts, and revocable trusts were the subject of extensive litigation in the 1930 s as courts and commentators debated whether they should be struck down for their failure to comply with the formalities required for wills. ${ }^{93}$ When the market accepted will substitutes, they became the future that rules could not force into the categories of the past. Their growing popularity, fueled in part by dissatisfaction with the inefficiency and expense of the probate process, became a standing reproach to formalistic adherence to the Wills Act formalities, which critics never failed to mention. ${ }^{94}$

It thus became a goal of some probate reformers to reconcile the law of wills and the law of will substitutes. Their progress was fitful. Philip Mechem denounced the wills provisions of the Model Probate Code in 1948 as "almost incredibly reactionary, unimaginative, and timid. ${ }^{n 95}$ A generation later, in 1969, the drafters of the Uniform Probate Code reduced the formalities "to a minimum," as they believed, with the stated purpose that "[i]f the will is to be restored to its role as the major instrument for disposition of wealth at death, its execution must be kept simple ${ }^{97}$-sidestepping the

${ }^{93}$ See, e.g., Orville F. Grahame, The Insurance Trust as Non-Testamentary Disposition, 18 MinN. L. Rev. 391, $391-410$ (1934); Guy B. Horton, The Testamentary Nature of Settlements of Life Insurance Elected by the Beneficiary, 17 CORNELL L.Q. 72, 73-97 (1931); C.W. Leaphart, The Trust as a Substitute for a Will, 78 U. PA. L. REV. 626, 626-38 (1930); Elmer I. Phillips, The Testamentary Character of Personal Unfunded Life Insurance Trusts, 82 U. PA. L. REV. 700, 703-31 (1934); Austin W. Scott, Trusts and the Statute of Wills, 43 HARV. L. REv. 521, $544-53$ (1930); Charles D. Seftenberg, The Border Lines of Agency, Living Trusts, and Testamentary Disposition, 5 WIS. L. REV. 321, 337-39 (1930). The first major criticism of formalism in wills drew heavily on the problems of classification presented by will substitutes. See Gulliver \& Tilson, supra note 10.

${ }^{94}$ See, e.g., Gulliver \& Tilson, supra note 10, at 18-39; John H. Langbein, The Nonprobate Revolution and the Future of the Law of Succession, 97 HARV. L. REV. 1108, 1115-25 (1984); Langbein, supra note 1, at 503-09; John H. Langbein, The TwentiethCentury Revolution in Family Wealth Transmission, 86 MICH. L. REv. 722, 746-50 (1988);

Lindgren, supra note 18 , at 556-57.

${ }^{95}$ Mechem, supra note 10 , at 501.

${ }^{96}$ UNIF. PROB. CODE $§ 2-502 \mathrm{cmt}$. (1969).

${ }^{97}$ Id. art. II, pt. 5 gen. cmt. (1969). 
question of why wills should be restored to predominance at all..$^{98}$ The 1990 Code, on the other hand, "accepts the inevitability of the will substitutes and attempts to deal with the consequences." ${ }^{\text {"99 }}$ The drafters identify the proliferation of will substitutes as one of the three sea changes addressed by the revised Code-changes in gender relations and a general decline of formalism in private law are the other two-and announce their intent "to bring the law of probate and nonprobate transfers into greater unison. ${ }^{p 100}$

Against this background, it should be clear that it is not the "intent-defeating" power of formalism that prompts reform. Rather, it is the need to fashion new categories for the future. "Intentdefeating" formalism has its value, as the progressive refinement of elective-share statutes attests. Formalism, even intent-defeating formalism, is intrinsically neither "good" nor "bad." It is not von Jhering's "anguished, pedantic cult of symbols wholly worthless and meaningless in themselves," not even when applied to the Wills Act formalities. ${ }^{101}$ Nor is it Weinrib's "effort to make sense of the lawyer's perception of an intelligible order, ${ }^{102}$ unless one ascribes intelligibility to the choice of default rules in antilapse and ademption. And it is not necessarily Schauer's "extreme and therefore unfortunate manifestation of a fundamentally desirable characteristic, ${ }^{103}$ at least not when it is the agent of particular policies of what testators should do with their property. Instead, its character derives from our judgment of what it accomplishes.

That judgment rests not so much on the strength or weakness of commitment to formalism in the abstract as it does on a belief that decisions about rules should not become too far removed from their political, economic, or social context-or, as Schauer phrased it, "formalism ... still has the burden of showing that it is appropriately used in a particular decisional domain."104 Formalism of the Wills Act formalities is hard pressed to sustain that burden in the face of will substitutes, which transmit more wealth, more efficient-

${ }^{98}$ In fairness, it should be noted that the drafters of the 1969 Code devoted most of their energies to reforming probate procedure in an attempt to correct at least some of the features that had driven people to avoid probate. See Langbein \& Waggoner, supra note 2, at 871-72.

${ }_{99} I d$. at 875 .

100 UNIF. PROB. CODE art. II prefatory note (1990).

101 VON JHERING, supra note 5.

102 Weinrib, supra note 6 , at 951 .

${ }^{103}$ Schauer, supra note 7 , at 548.

${ }^{104} \mathrm{Id}$. at 544. 
ly, with fewer formalities. Formalism of the default rules of intestate succession or of the elective share, on the other hand, carry the burden by their congruence with prevailing views of the responsibility of property owners to their families.

When the categories of the past can no longer accommodate the present, they must eventually change or be abandoned-hence the dispensing power of $\S 2-503$ and the refinements of intestate succession and the elective share. The revised Uniform Probate Code is thus not about "the fall of formalism" 105 or "curing intentdefeating formalism." 106 It is about moving the law of wills into the future-a task for which formalism is sometimes useful, and sometimes not.

${ }^{105}$ Lindgren, supra note 3, at 1009.

${ }^{106}$ Langbein \& Waggoner, supra note 2, at 874. 